\title{
ANALISIS HUKUM ISLAM TERHADAP JUAL BELI ONLINE
}

\author{
Nurul Afifah \\ UIN Sunan Ampel, Jl. A. Yani 117 Surabaya \\ Email:afifahnurul673@gmail.com \\ Nur Lailatul Musyafa'ah \\ UIN Sunan Ampel, Jl. A. Yani 117 Surabaya \\ Email:nurlailatul@uinsby.ac.id
}

\begin{abstract}
This article discusses the analysis of Islamic law on buying and selling online. This research is literature and qualitative research. Data were collected through books, journals, and documents and analyzed descriptively. The study results conclude that buying and selling online is a sale and purchase transaction of goods carried out by two parties, namely the seller and the buyer, through the internet. In Islamic law, buying and selling online is legal, and the contract is valid on the condition that the goods purchased are halal and have precise specifications, the goods to be bought are following their needs. The buyer has the right to cancel or accept if the goods are not following the order. The sale and purchase are considered fi hukm ittihad al-majlis (in the position of one assembly). Ittihad al-majlis can be interpreted in three ways, namely ittihad al-makan (one place) and ittihad al-zaman (time of time), and ittihad al-haiah (one position). With modern communication media, it is possible to unite two places that are far apart, so that the two places are considered to be one (taaddud al-makan fi manzilah ittihad al-makan). Online buying and selling transactions carried out in two far apart areas are included in ittihad almajlis in the ittihad al-zaman category (one time).Islam allows buying and selling online as long as there is no element of fraud between the two parties in the contract. It has fulfilled the conditions and pillars following the provisions of Islamic law.
\end{abstract}

Keywords: Buy and sell, online, Islamic law.

Abstrak: Artikel ini membahas tentang analisis hukum Islam terhadap jual beli online. Penelitian ini adalah penelitian pustaka dan kualitatif. Data dikumpulkan melalui buku, jurnal dan dokumen, yang kemudian dianalisis secara deskriptif. Hasil penelitian menyimpulkan bahwa jual beli online adalah transaksi jual beli terhadap barang, yang dilakukan dua pihak yaitu penjual dan pembeli melalui media internet. Dalam hukum Islam, jual beli online hukumnya boleh dan akadnya sah dengan syarat barang yang dibeli halal dan jelas spesifikasinya, barang yang akan dibeli sudah sesuai dengan kebutuhan, dan pembeli memiliki hak untuk membatalkan atau menerima jika barang tidak sesuai pesanan. Jual beli tersebut dianggap fi hukm ittihad al-majlis (dalam posisi satu majelis). Ittihad al-majlis bisa diartikan dengan tiga hal yaitu ittihad al-makan (satu tempat) dan ittihad al-zaman (waktu waktu), dan ittihad al-haiah (satu posisi). Dengan adanya media komunikasi modern, bisa menyatukan dua tempat yang berjauhan, sehingga kedua tempat tersebut dianggap menjadi satu (taaddud al-makan fi manzilah ittihad al-makan). Transaksi jual beli online yang dilakukan di dua tempat yang berjauhan termasuk dalam ittihad al-majlis dalam kategori ittihad al-zaman (satu waktu). Islam

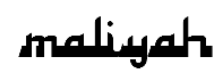

Jurnal Hukum Bisnis Islam

Volume 09, Nomor 01, Juni 2019

p-ISSN: 2088-4869/ e-ISSN: 2597-4351 
Hukum Jual Beli melalui Media Sosial ...

membolehkan jual beli online selama dalam akad tersebut tidak ada unsur penipuan antara kedua belah pihak, dan telah memenuhi syarat-syarat dan rukun sesuai dengan ketentuan hukum Islam.

Kata kunci: Jual beli, online, hukum Islam.

\section{Pendahuluan}

Berdagang maupun berbisnis merupakan salah satu aktivitas yang sangat dianjurkan dalam ajaran Islam, bahkan Rasulullah SAW sendiri dalam salah satu hadisnya mengatakan bahwa sembilan dari sepuluh pintu rezeki adalah melalui pintu berdagang. Artinya, melalui jalan perdagangan inilah, pintupintu rezeki akan dapat dibuka sehingga karunia Allah SWT terpancar dari padanya. Jual beli merupakan sesuatu yang diperbolehkan oleh Allah SWT sebagaimana firmanNya dalam QS. Al-Baqarah/2: 275 yang berbunyi:

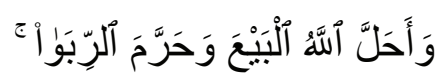

"Allah telah menghalalkan jual beli dan mengharamkan riba...",

Jual beli harus dilakukan dengan cara yang benar dan sesuai dengan aturan ajaran Islam. ${ }^{1}$ Aturan jual beli juga dijelaskan dalam firmanNya QS. A-Nisa/4: 29 yang berbunyi:

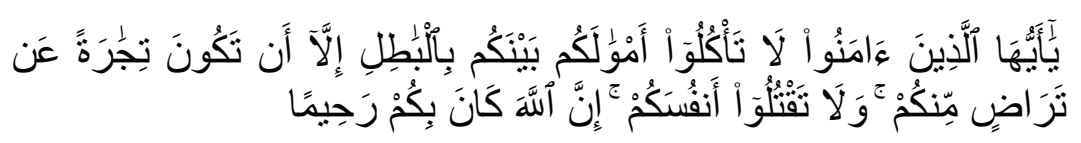

Hai orang-orang yang beriman, janganlah kamu saling memakan harta sesamamu dengan jalan yang batil, kecuali dengan jalan perniagaan yang berlaku dengan suka sama-suka di antara kamu. Dan janganlah kamu membunuh dirimu; sesungguhnya Allah adalah Maha Penyayang kepadamu. ${ }^{2}$

Jual beli adalah saling menukar benda dengan sesuatu yang sepadan dan melalui cara tertentu. Jual beli telah dipraktikkan dari zaman masyarakat primitif dengan sistem

\footnotetext{
1 Munir Salim, "Jual Beli Secara Online Menurut Pandangan Hukum Islam," Ad-Daulah 6, no. 2 (2017), 372.

2 Departemen Agama RI, Al-Qur'an Dan Terjemahnya (Jakarta: Departemen Agama RI, n.d.), 107.
} 
barter. ${ }^{3}$ Seiring dengan perkembangan kebudayaan dan teknologi, jual beli yang dulunya hanya barter yaitu pertukaran barang dengan barang, berubah dengan alat transaksi berupa uang, maka transaksi jual beli mulai dilaksanakan dengan pertukaran barang dengan uang. ${ }^{4}$ Sedangkan pada era modern dan era teknologi saat ini, jual beli tidak harus berhadapan langsung tetapi sudah bisa via internet dan telepon, atau jual beli melalui kartu debit (debet card) dan pembayaran melalui cek/giro. ${ }^{5}$

Jual beli melalui internet disebut sebagai jual beli online. Jual beli online diartikan sebagai jual beli barang dan jasa melalui media elektronik, khususnya melalui internet atau secara online, yang mana transaksi jual beli ini tidak mengharuskan penjual dan pembeli bertemu secara langsung atau saling menatap muka secara langsung, dengan menentukan ciri-ciri, janis barang, sedangkan untuk harganya dibayar terlebih dahulu baru diserahkan barangnya.

Media sosial adalah sebuah media online dengan para penggunanya bisa dengan mudah berpartisipasi, berbagi, dan menciptakan isi meliputi blog, jejaring sosial, dan dunia virtual. Semua itu merupakan bentuk media sosial yang paling umum digunakan oleh masyarakat di seluruh dunia. Media sosial terbesar antara lain instagram, facebook, myspace dan twitter. Dengan demikian banyak masyarakat yang menjadikan media sosial khususnya facebook sebagai salah satu media pemasaran untuk jual beli online dan promosi bisnis.

Dalam jual beli online, penjual harus memiliki sikap yang baik yaitu menepati janji, menepati waktu, memperbaiki kelemahan dan kekurangan, memperbaiki kualitas barang dan tidak boleh menipu atau berbohong. Karena itu, penjual harus

3 Umi Riyanti, "Jual Beli Barter Dalam Perspektif Ekonomi Syariah" (IAIN Palangkaraya, 2016), 7.

4 Disa Nusia Nisrina, "Tinjauan Hukum Islam Terhadap Jual Beli Online Dan Relevansinya Terhadap Undang-Undang Perlindungan Konsumen" (UIN Alauddin Makassar, 2015), 3.

5 Santi Endriani, "Konsep Uang: Ekonomi Islam vs Ekonomi Konvensional," Anterior 15, no. 1 (2015), 70-71.

\section{maliyath}


senantiasa amanah, terbuka, jujur, melayani secara optimal, dan berbuat baik kepada setiap orang, khususnya pembeli dan pelanggan. Dengan sifat tersebut, pelaku usaha harus bertanggungjawab dalam melaksanakan tugasnya. ${ }^{6}$

Di lapangan banyak terjadi permasalahan yang menimbulkan kerugian bagi para konsumen atau pembeli, seperti penipuan jual beli online di media sosial dengan modus penjualan handphone dan elektronik dengan mengaku barang BM (Black Market) dari Batam serta harga yang jauh lebih murah dari harga pasaran. ${ }^{7}$ Contoh lain biasanya kualitas barang yang dijual tidak sesuai dengan spesifikasi yang telah dicantumkan karena di sini pembeli tidak bisa melihat secara langsung barang yang akan di beli, kebanyakan yang terjadi barang yang dibeli tidak sesuai dengan yang ada di postingan (gambar), kasus lain, biasanya ketika pembeli sudah melakukan pembayaran (transfer uang) namun barang tidak kunjung diantar. Dari sini terjadi potensi penipuan yang sangat tinggi dan juga yang nantinya akan menimbulkan kerugian bagi para pembeli dan masih banyak lagi permasalahan yang terjadi dalam jual beli online.

Berdasarkan hal tersebut, penulis tertarik membahas artikel tentang hukum Jual Beli dalam perspektif hukum Islam.

Jenis penelitian ini menggunakan model pendekatan penelitian kualitatif dengan jenis penelitian deskriptif analisis. Metode pengumpulan data yang digunakan dalam penelitian ini adalah metode kepustakaan (library research), penelitian perpustakaan yang dilakukan dengan mengkaji buku-buku, skripsi, jurnal dan bahan-bahan lainnya yang mempunyai relevansi dengan pokok pembahasan penelitian ini. Setelah semua data yang dibutuhkan terkumpul dan dikelola oleh penulis untuk dianalisis secara mendalam.

6 Veithzal Rival and Andi Buchari, Islamic Economics: Ekonomi Syariah Bukan OPSI, Tapi Solusi! (Jakarta: Bumi Aksara, 2009), 237.

${ }^{7}$ www.kompasiana.com 


\section{Konsep Jual Beli dalam Hukum Islam}

Secara bahasa al-ba'i artinya pertukaran secara mutlaq. Kata al-bai' (jual) dan al-syira' (beli) pemakaiannya sama antara keduanya. Adapun secara syariat, jual beli adalah pertukaran harta dengan harta atas dasar keridhaan antara keduanya atau mengalihkan kepemilikan barang dengan kompensasi (pertukaran) berdasarkan cara yang dibenarkan syariat. ${ }^{8}$ Ulama Hanafiyah mendefinisikan jual beli sebagai berikut:

"Saling menukar harta dengan melalui cara tertentu" atau

"Tukar menukar sesuatu yang diingini dengan yang sepadan melalui cara tertetu yang bermanfaat".

Ulama syafi'iyah mendefinisikan jual beli sebagai berikut:

"Jual beli menurut syara' adalah suatu akad yang mengandung tukar menukar harta dengan harta dengan syarat yang akan diuraikan nanti untuk memperoleh kepemilikan atas benda atau manfaat untuk waktu selamanya".

Jual beli diperbolehkan berdasarkan al-Qur'an, as-Sunnah, ijma' dan qiyas. Allah SWT berfirman dalam QS. Al-Baqarah: 275 yang berbunyi:

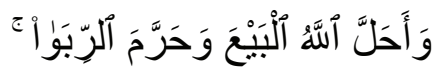

"Allah telah menghalalkan jual beli dan mengharamkan riba...",

Rasulullah SAW bersabda:

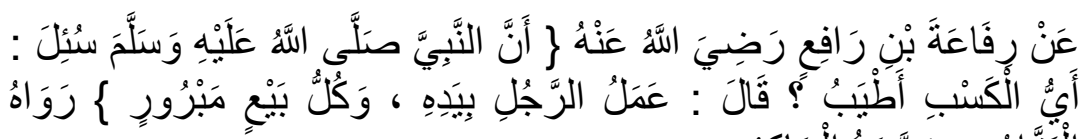

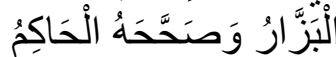

Dari Rifa'ah bin Rafi', Nabi pernah ditanya mengenai pekerjaan apa yang paling baik. Jawaban Nabi, "Kerja dengan tangan dan semua jual beli yang mabrur" [HR Bazzar no 3731 dan dinilai shahih oleh al Hakim. Baca Bulughul Maram no 784].

8 Sulaiman Al-Faifi, Ringkasan Fiqih Sunnah Sayyid Sabiq (Depok: Senja Media Utama, 2017), 595. 
Jual beli tidak terlepas dari syarat. Syarat dalam jual beli adalah komitmen yang dijalin antara salah satu dari beberapa pihak yang mengadakan transaksi dengan lainnya untuk mengambil manfaat dari barang tersebut. Menurut mereka, sebuah syarat dalam jual beli tidak dianggap berlaku, kecuali jika tidak disebutkan dalam inti akadnya. Dengan demikian tidak dianggap sah sebuah syarat yang dibuat sebelum akad atau setelah akad dibuat. ${ }^{9}$

Jual beli memiliki dua macam syarat, yaitu syarat sah dan syarat yang dapat membatalkan jual beli.

Syarat sah merupakan syarat yang telah sesuai dengan tuntutan akad. Syarat ini ada tiga maam, yaitu: 1 . Syarat yang menjadi tuntutan jual beli seperti serah terima barang dan pembayaran tunai. 2. Syarat yang memiliki kemaslahatan dalam akad seperti menangguhkan pembayaran, atau menangguhkan sebagian pembayaran, atau syarat ciri-ciri khusus pada barang. 3. Syarat yang tidak diketahui oleh penjuan atau pembeli seperti jika seseorang telah menjual rumah kemudian ada yang membeli manfaat rumah tersebut selama waktu tertentu, contohnya untuk ditempati selama satu atau dua bulan.

Syarat yang kedua adalah syarat yang dapat membatalkan akad, dalam hal ini ada tiga macam:

1. Syarat yang membatalkan sejak awal, misalnya: salah satu pihak yang melakukan akad membuat syarat lain kepada lainnya. Contoh: penjual berkata kepada pembeli," aku menjual barang ini kepadamu dengan syarat engkau menjualnya kepadaku" atau "Beri aku pinjaman." Dalilnya adalah sabda Rasulullah SAW:

"Tidak boleh menggabungkan akad jual beli dan akad pinjam meminjam, dan tidak boleh pula menggabungkan dua syarat dala satu transaksi." Hadis ini diriwayatkan oleh Imam Tirmizi dan dishahihkan olehnya.

9 Saleh Al-Fauzan, Fiqih Praktis Sehari-Hari (Jakarta: Gema Insani, 2005), 373. 
2. Syarat yang mengesahkan jual beli tapi syarat tersebut batal. Itulah syarat yang menafikan konsekuensi akad. Misalnya: penjual mensyaratkan pembeli agar tidak menjual atau menghibahkan barang yang ia beli. Hal ini berdasarkan sabda Rasulullah:

"Setiap syarat yang tidak berasal dalam kitab Allah adalah batil, meskipun sebanyak seratus syarat." Hadis ini diriwayatkan oleh Imam Bukhari dan Imam Muslim.

3. Syarat yang tidak mengesahkan jual beli, seperti penjual berkata," Aku jual barang ini kepadamu jika di Fulan rela," atau, "Aku jual barang ini kepadamu jika engkau membawa barang ini dan itu." Begitu juga setiap jual beli yang dikaitkan dengan syarat pada masa mendatang. ${ }^{10}$

Selain syarat, jual beli harus memiliki rukun. Dalam menentukan rukun jual beli terdapat perbedaan pendapat ulama Hanafiyah dan jumhur ulama. Rukun jual beli menurut Hanafiyah hanya satu, yaitu ijab (ungkapan membeli dari pembeli) dan qabul (ungkapan menjual dari penjual). Menurut mereka, yang menjadi rukun dalam jual beli itu hanyalah kerelaan kedua belah pihak untuk melakukan transaksi jual beli. Akan tetapi jumhur ulama menyatakan bahwa rukun jual beli itu ada empat, yaitu:

1. Ada orang yang berakad atau al-muta'aqidain (penjual dan pembeli).

2. Ada shighat (lafal ijab qabul).

3. Ada barang yang dibeli.

4. Ada nilai tukar pengganti barang. ${ }^{11}$

Akad ialah ikatan kata antara penjual dan pembeli. Jual beli belum dikatakan sah apabila sebelum ijab dan qabul dilakukan, sebab ijab qabul menunjukkan kerelaan (keridlaan). Pada dasarnya ijab qabul dilakukan dengan lisan, tetapi kalau tidak mungkin, misalnya bisu atau yang lainnya, boleh ijab

10 Al-Faifi, Ringkasan Fiqih Sunnah Sayyid Sabiq, 608.

11 Abdul Rahman Ghazali, Fiqih Muamalat (Jakarta: Fajar Interpratama Offset, 2010), 71.

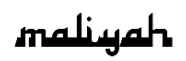


qabul dengan surat menyurat yang mengandung arti ijab qabul. ${ }^{12}$

Jual beli dianggap sah jika dilakukan dengan ijab qabul, kecuali barang-barang kecil maka tidak wajib dengan ijab dan qabul, tetapi cukup dengan mu'athah (saling memberi saja). Dan hal itu merujuk pada kebiasaan yang berlaku di masyarakat tersebut. Ijab dan qabul tidak mewajibkan katakata tertentu, sebab yang menjadi ukuran dalam jual beli adalah akad dan tujuannya, bukan kata-kata dan bentuknya. ${ }^{13}$

Syarat bagi subyek yang berakad adalah: 1. Mumayyiz, maka orang gila dan anak yang belum mumayyiz tidak boleh melakukan akad jual beli. Bagi yang belum mumayyiz harus memperoleh izin dari walinya secara khusus untuk jual beli. ${ }^{14}$ 2. Tidak ada paksaan, sebagaimana firman Allah SWT:

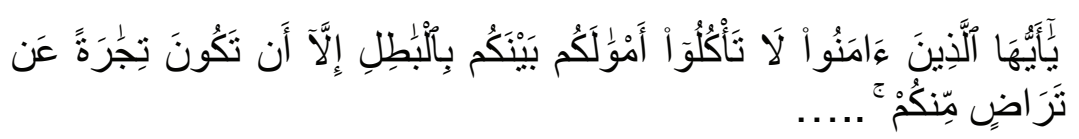

Hai orang-orang yang beriman, janganlah kamu saling memakan harta sesamamu dengan jalan yang batil, kecuali dengan jalan perniagaan yang berlaku dengan suka sama-suka di antara kamu.....

Berkaitan dengan ijab qabul, maka harus memenuhi syarat sebagai berikut: Tidak ada sela atau jeda di antara waktu ijab qabul penjual dan pembeli, dan tidak diselingi dengan katakata lain dalam ijab qabul.

Benda yang menjadi objek akad jual beli disyaratkan sebagai berikut: 1. Barangnya suci. 2. Barangnya bermanfaat. 3 . Barangnya milik penjual. 4. Barangnya dapat diserahkan. 5.

${ }^{12}$ Hendi Suhendi, Fiqh Muamalah (Jakarta: PT Raja Grafindo Persada, 2013), 70.

${ }^{13}$ Al-Faifi, Ringkasan Fiqih Sunnah Sayyid Sabiq, 595.

14 Siah Khosyi'ah, Fiqih Muamalah Perbandingan (Bandung: CV Pustaka Setia, 2014), 90.

15 Departemen Agama RI, Al-Qur'an Dan Terjemahnya (Jakarta: Departemen Agama RI, n.d.), 107. 
Barang yang dijual dan harganya harus jelas. 6. Perikatan itu tidak dibatasi waktu.

Benda-benda yang tidak boleh diperjualbelikan, yaitu sebagai berikut: Jual beli benda najis dan mutanajjis, memperjualbelikan burung yag masih di udara, jual beli barang yang haram, jual beli binatang yang masih di perut induknya, jual beli yang mengandung kemadharatan, ${ }^{16}$ jual beli benda yang tidak terlihat (ghaib), ${ }^{17}$ dan jual beli dan jual beli barang yang tidak jelas. ${ }^{18}$

Jual beli barang yang tidak jelas atau samar-samar, hukumnya haram karena dapat merugikan penjual atau pembeli, seperti menjual putik mangga untuk dipetik kalau telah tua/masak nanti. ${ }^{19}$ Hal tersebut sebagaimana hadis Ibnu Umar r.a., yang mengatakan bahwa Nabi Muhammad SAW melarang memperjualbelikan buah-buahan hingga jelas kemaslahatannya.

"Telah menceritakan kepada kami Abu al-Walid telah menceritakan kepada kami Syu'bah dari 'Amru dari Abu alBakhtary berkata:"Aku bertanya kepada Ibnu Umar r.a. tentang as-Salam pada pohon kurma. Maka dia berkata: "Dilarang menjual pohon kurma hingga buahnya baik (bisa dimakan) dan dilarang pula menjual emas dengan cara tempo". Dan aku bertanya kepada Ibnu Abbas r.a tentang as-Salam pada pohon kurma. Maka dia menjawab: "Nabi Saw melarang jual beli pohon kurma hingga buahnya bisa dimakan atau dapat dimakan dan hingga ditimbang.".

Selain itu dilarang Jual beli qablal-qabdhi, yaitu menjual barang sebelum diterima oleh pembeli. Jual beli seperti ini fasid berdasarkan sabda Rasulullah SAW:

“Telah bercerita kepadaku Yahya dari Malik dari Nafi' dari Abdullah bin Umar bahwasannya Rasulullah SAW bersabda:

\footnotetext{
16 Hendi Suhendi, Fiqih Muamalah, (Jakarta: Raja Grafindo Persada, 2008), 79.

17 Nasrun Harun, Fiqih Muamalah (Jakarta: Gaya Media Pratama, 2007), 126.

18 Khosyi'ah, 102.

${ }^{19}$ Ghazali, Fiqih Muamalat, 82.
}

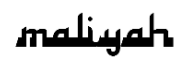


barang siapa yang membeli makanan, janganlah menjualnya lagi sampai ia menerimanya".

Larangan jual beli ini karena barang belum dimiliki oleh pembeli sehingga masih menjadi tanggungan penjual. Demikian juga, dilarang menyewakan dan menggadaikannya, tetapi pembeli dapat mentransaksikan barang yang ada ditangan orang lain sebagai amanat, misalnya dititipkan.

\section{Ketentuan Jual Beli Online (as-Salam)}

As-Salam adalah ism mashdar dari fi'il madhi aslama. Secara bahasa, salam berarti menyegerakan dan mendahulukan uang pembayaran (modal). Secara bahasa, "salam" juga disebut "salaf", hanya saja kata "salam" adalah bahasa ahli Hijaz dan "salaf" bahasa ahli Iraq. ${ }^{20}$

Dalam Islam, hukum salam adalah boleh karena ia bagian dari rukhshah (keringanan) yang dikecualikan dari jual beli barang yang tidak ada di tempat penjual. Hukum salam diperbolehkan berdasarkan al-Qur'an, sunnah dan ijma'. Dasar hukum salam dari al-Qur'an ialah terdapat dalam Q.S. alBaqarah: 282, yang berbunyi:

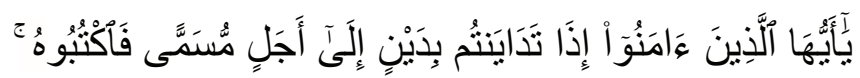

"Hai orang-orang yang beriman, apabila kamu berhutang satu sama lain, sampai kepada waktu yang ditentukan, hendaklah kamu menuliskan hutang itu....". (Q.S alBaqarah :282).

Salam adalah pembayaran di muka dan penyerahan barang di kemudian hari, yang didefinisikan oleh para fuqaha sebagai "akad jual beli atas sesuatu yang disebutkan kriterianya dalam akad dan yang dijanjikan akan diserahkan pada waktunya yang ditentukan nanti kepada pembeli, dengan pembayaran yang diserahkan pada saat transaksi itu".21

20 Abdulrahman Al-jaziri, Fiqih Empat Madzhab (Semarang: CV Asy-Syifa, 1994)., 585

${ }^{21}$ Al-Fauzan, Fiqih Praktis Sehari-Hari, 406. 
Berdasarkan hal tersebut, maka hal yang menjadi rukun dan syarat jual beli menjadi rukun dan syaratnya salam juga. Untuk menghindari pertikaian antara penjual dan pembeli, maka salam hanya sah pada barang yang dapat dibatasi dengan sifatsifat tertentu seperti barang yang diperjulbelikan berdasarkan takaran, timbangan, hitungan atau meteran. ${ }^{22}$

Selain itu dalam akad salam, terdapat beberapa syarat yang harus disebutkan di dalam akad, yaitu: 1. Menyebutkan jenis barang yang dipesan dan jenis modal, 2. Menjelaskan macam dan sifatnya, 3. Menjelaskan jumlahnya jika barangnya bisa dihitung, menjelaskan kadarnya, menjelaskan takarannya bagi barang yang ditakar, menjelaskan timbangannya bagi barang yang ditimbang, menjelaskan ukurannya bagi barang yang diukur. 4. Hendaknya barang yang dipesan itu ditangguhkan hingga masa tertentu, sedikitnya satu bulan. Oleh karena itu tidak sah bila barang yang dipesan itu diserahkan seketika itu. Sedangkan modal (harga) justru disyaratkan harus kontan sebagaimana dijelaskan dalam beberapa mazhab. ${ }^{23}$

\section{Konsep Jual Beli Online}

Perkembangan zaman saat ini sangat cepat dan kompleks, sehingga mempengaruhi kebutuhan hidup manusia. Perkembangan teknologi di bidang komunikasi menjadikan manusia bisa berkomunikasi dengan mudah meskipun secara jarak jauh, seperti jual beli. Saat ini, jual beli bisa dilakukan dari jarak jauh tanpa harus melihat bahkan tanpa mengenal satu sama lain sebelumnya. Lahirnya situs-situs di internet yang menyediakan ruang untuk melakukan kegiatan jual beli, menjadikan transaksi tersebut lebih mudah meskipun tanpa harus melihat secara riil atas objek apa yang akan dibelinya. Situs tersebut menyediakan macam-macam barang, mulai dari barang elektronik, pakaian, makanan atau pun yang lainnya

22 Al-jaziri, Fiqih Empat Madzhab, 590.

23 Khosyi'ah, Fiqih Muamalah Perbandingan, 72.

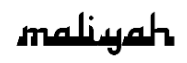


dengan konsep kenyamanan, aman kepercayaan dan tentu saja dengan biaya murah. ${ }^{24}$

Dengan adanya internet, mengelola bisnis menjadi lebih mudah, karena bisa diakses dimana saja dan kapan saja. Bisnis melalui internet bisa dilakukan dengan melalui beberapa cara, di antaranya; 1. Melalui media sosial seperti, Facebook, Instagram, dan Twitter. 2. Melalui Personal Website atau blog pribadi khusus untuk merek dagangnya sendiri. 3. Melaui On line Shop seperti Lazada, Mataharimall.com, Zalora, La Zada, Bukalapak.com, blibli.com, Tokopedia, Elevania dan lainnya. ${ }^{25}$

Dalam transaksi jual beli online, pembeli dapat melihat barang atau jasa yang ditawarkan pada layar monitor, namun obyek tersebut tidak bisa seketika diperoleh karena harus menunggu dikirim oleh pihak penjual. Lamanya masa pengiriman tergantung dari lokasi (tempat tinggal atau kantor) pembeli dan pemilihan jasa kurir dalam pengiriman. Disamping itu pembeli tidak dapat langsung memeriksa kondisi barang yang akan ia beli, apakah sesuai dengan spesifikasi yang telah dicantumkan di toko online nya, apakah ada cacatnya atau tidak. ${ }^{26}$

Transaksi secara online merupakan transaksi pesanan dalam model bisnis era global yang tanpa bertatap muka langsung, dengan hanya melakukan transfer data lewat dunia maya (data intercange) via internet antara kedua belah pihak yaitu penjual dan pembeli.

Bisnis online dikenal juga dengan istilah e-business atau ecommerce. e-business atau e-commerce adalah semua bentuk

\footnotetext{
24 Budi Bahreysi, "Perlindungan Hukum Bagi Konsumen Dalam Jual Beli Secara Online," De Lega Lata: Jurnal Ilmu Hukum 3, no. 2 (2018): 132, http://journal.umsu.ac.id/index.php/delegalata/article/view/3157/2873. 25 Wati Susiawati, "Jual Beli Dalam Konteks Kekinian," Jurnal Ekonomi Islam 8, no. 2 (2017): 180-82, https://journal.uhamka.ac.id/index.php/jei/article/view/836.

26 Retno Dyah Pekerti and Eliada Herwiyanti, "Transaksi Jual Beli Online Dalam Perspektif Syariah Madzhab Asy-Syafi'i," Jurnal Ekonomi, Bisnis, Dan $\begin{array}{lllll}\text { Akuntansi } & 20, & \text { no. } & 2018): & \text { 4, }\end{array}$ http://jp.feb.unsoed.ac.id/index.php/jeba/article/view/1108.
} 
transaksi komersial, yang menyangkut organisasi dan transmisi data yang digeneralisasikan dalam bentuk teks, suara, dan gambar secara lengkap.

Selain itu, terdapat beberapa pengertian lain tentang ebusiness atau e-commerce, di antaranya:

a. E-business merupakan praktik pengelolaan dan pelaksanaan proses bisnis utama seperti perancangan produk, pengelolaan pasokan bahan baku, manufaktur, penjualan, pemenuhan pesanan, dan penyediaan servis melalui penggunaan teknologi komunikasi, komputer, dan data yang telah terkomputerisasi dengan hanya melakukan transfer data lewat dunia maya (data intercange) melalui internet antara kedua belah pihak (penjual dan pembeli).

b. E-business adalah semua hal yang berkaitan dengan kegiatan bisnis antar sesama organisasi atau antara organisasi dan konsumen, yang dilakukan menggunakan teknologi informasi dan komunikasi (Information Communication Technology).

c. Penggunaan internet dan teknologi digital lainnya untuk komunikasi, koordinasi, dan manajemen organisasi. ${ }^{27}$

Berdasarkan pengertian di atas diketahui bahwa jual beli online adalah transaksi jual beli antara penjual dan pembeli terhadap produk suatu barang dengan menggunakan media internet sebagai alat komunikasinya.

\section{Jual Beli Online Menurut Hukum Islam}

Dalam dunia modern seperti sekarang, kemajuan teknologi sangat pesat dan mengalami kemajuan termasuk dalam perkembangan bisnis dalam jual beli online melalui media sosial khususnya facebook, yang mana semua orang bisa melakukan transaksi jual beli dengan sangat mudah dan cepat. Namun, di sisi lain untuk melakukan transaksi setiap orang harus mengetahui dan paham apa saja syarat-syarat dan rukun

27 Rodame Monitorir Napitupulu, "Pandangan Islam Terhadap Jual Beli Online," At-Tijaroh 1, no. 2 (2015): 130, http://repo.iainpadangsidimpuan.ac.id/293/1/Rodame Monitorir Napitupulu.pdf.

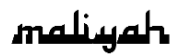


dalam jual beli supaya transaksi jual beli menjadi sah dan bermanfaat bagi penjual dan pembeli. Karena dalam fatwa DSN MUI Nomor 24 Tahun 2017 tentang fatwa hukum dan bermuamalah melalui media sosial, menjelaskan bahwa bermuamalah melalui media sosial harus dilakukan tanpa melanggar ketentuan agama dan ketentuan peraturan perundang-undangan. ${ }^{28}$

Menurut Oni Syahroni, anggota DSN MUI, hukum jual beli online adalah boleh dengan syarat barang yang dibeli adalah barang yang halal dan spesifikasinya jelas, barang tersebut merupakan barang yang dibutuhkan (tidak ada unsur tabdzir), pembeli memiliki hak untuk melanjutkan atau membatalkan akad jual beli jika barang yang diterima tidak sesuai dengan pesanan, dan jual beli online telah sesuai dengan skema jual beli. $^{29}$

Skema jual beli yang harus diperhatikan adalah: Pertama, berkaitan dengan barang yang dibeli. Dalam fatwa DSN MUI tentang salam dijelaskan bahwa barang yang dibeli harus memenuhi syarat sebagai berikut: Harus jelas ciri-cirinya dan dapat diakui sebagai hutang, harus dapat dijelaskan spesifikasinya, penyerahannya dilakukan kemudian, waktu dan tempat penyerahan barang harus ditetapkan berdasarkan kesepakatan, pembeli tidak boleh menjual barang sebelum menerimanya, dan tidak boleh menukar barang, kecuali dengan barang sejenis sesuai kesepakatan. ${ }^{30}$

Kedua, bagaimana cara membelinya. Transaksi jual beli diperbolehkan baik secara tunai maupun non tunai. Hal tersebut didasarkan pada hasil keputusan Majma' al-Fiqh alIslami (Divisi Fikih Organisasi Kerja sama Islam/OKI) No. 51

28 Majelis Ulama Indonesia, "Fatwa Majelis Ulama Indonesia Nomor 24 Tahun 2017 Tentang Hukum Dan Pedoman Bermuamalah Melalui Media Sosial" (Jakarta, 2017).

29 "Konsultasi Syariah Fikih Belanja Online," Republika.Co.Id, October 18, 2008 , http://m.republika.co.id/berita/ekonomi/syariahekonomi/18/10/08/pg8ieo370-konsultasi-syariah-fikih-belanja-online.

30 Dewan Syari'ah Nasional MUI, "Fatwa Dewan Syari'ah Nasional No: 05/DSN-MUI/IV/2000 Tentang Jual Beli Salam” (Jakarta, 2000). 
(2/6) 1990 yang membolehkan jual beli tidak tunai dan fatwa DSN MUI No. 04/DSN-MUI/IV/2000 tentang Murabahah ${ }^{31}$, dan hadis Nabi Muhammad SAW, yang artinya: "Dan kaum muslimin terikat dengan syarat-syarat mereka kecuali syarat yang mengharamkan yang halal atau menghalalkan yang haram." (HR. Tirmidzi)

Berdasarkan hal di atas, maka jual beli online hukumnya boleh dan akadnya sah, sebagaimana pendapat ulama ahli fiqih yang membolehkan transaksi antara penjual dan pembeli yang berbeda tempat, juga pendapat mayoritas ulama yang membolehkan transaksi atas barang inden atau ready stock, tetapi diserahterimakan/dikirim oleh penjual online kemudian transaksi ini dikenal dengan al-Bai' al-Maushuffi Dzimmah atau jual beli dengan objek jual yang inden atau tidak tunai, tetapi bisa diketahui spesifikasi dan karakteristiknya. Jual beli online juga diperbolehkan berdasarkan keputusan Standart Akuntansi Syariah Internasional AAOIFI (Accounting and Auditing Organizations for Islamic Financial Institutions) yang membolehkan ijab qabul dan serah terima secara online jika tradisi pasar dan otoritas mengakui hal tersebut. ${ }^{32}$

Menurut fatwa Nahdlatul Ulama, jual beli online hukumnya boleh dan akadnya sah. Jual beli yang menggunakan media online, misalnya teleconference, telepon, surat elektronikk (email), media sosial facebook, sms, atau aplikasi jual beli online, hukumnya boleh dan akadnya sah. Jual beli tersebut dianggap fi hukm ittihad al-majlis (dalam posisi satu majelis) karena memenuhi rukun dan syarat jual beli, yaitu terdapat muta'aqidani (kedua belah pihak yang bertransaksi, penjual dan pembeli) yang saling mengetahui, objeknya (almabi') diketahui dapat diketahui sehingga tidak ada unsur gharar (ketidaktahuan), dan terdapat ijab qabul yang didasari suka sama suka (taradhin).

\footnotetext{
31 Dewan Syariah Nasional MUI, "Fatwa DSN MUI No. 04/DSN-MUI/IV/2000 Tentang Murabahah" (Jakarta, 2000).

32 "Konsultasi Syariah Fikih Belanja Online."
} 
Dalam jual beli disyariatkan ittihad al-majlis. Hal tersebut didasarkan pada pendapat Yahya bin Syaraf al-Nawawi dalam bukunya Raudhah al-Thalibin wa 'Umdah al-Muftin:

Yang dimaksud dengan majlis yang disyaratkan memberi di dalamnya adalah majlis tawajub (saling menetapkan), yaitu majlis yang menghasilkan keterkaitan antara ijab dan qabul, dan tidak ada pertimbangan atas tempat akad. ${ }^{33}$

Ittihad al-majlis bisa diartikan dengan tiga hal yaitu ittihad al-makan (satu tempat) dan ittihad al-zaman (waktu waktu), dan ittihad al-haiah (satu posisi). Dengan adanya media komunikasi modern, bisa menyatukan dua tempat yang berjauhan, sehingga kedua tempat tersebut dianggap menjadi satu (taaddud al-makan fi manzilah ittihad al-makan). ${ }^{34}$ Transaksi jual beli online yang dilakukan di dua tempat yang berjauhan termasuk dalam ittihad al-majlis dalam kategori ittihad al-zaman (satu waktu).

Ittihad al-majlis adalah adanya kesatuan tempat yang memiliki pengaruh yang besar dalam akad/transaksi muamalah diantaranya akad jual beli dan akad nikah. Saat ini, konsep ittihad al-majlis dalam akad jual beli mengalami pergeseran makna seiring dengan kemajuan teknologi khususnya di bidang komunikasi. Akad jual beli yang terjadi seringkali tidak berada di satu tempat seperti jual beli ekspor/impor dengan menggunakan media telekomunikasi modern. Pada dasarnya, ijab qabul harus jelas dalam setiap akad dan media komunikasi modern ternyata mampu memberikan jaminan kejelasan antara ijab dan qabul. ${ }^{35}$

33 Ahkamul Fuqaha, Solusi Problematika Aktual Hukum Islam Keutusan Muktamar, Munas, Konbes Nahdlatu Ulama 1926-2010 M (Surabaya: Lajnah Ta'lif Wan Nasyr (LTN) Pengurus Besar Nahdlatul Ulama dan Khalista, 2011), 890.

34 Ahkamul Fuqaha, Solusi Problematika Aktual Hukum Islam Keutusan Muktamar, Munas, Konbes Nahdlatu Ulama 1926-2010 M (Surabaya: Lajnah Ta'lif Wan Nasyr (LTN) Pengurus Besar Nahdlatul Ulama dan Khalista, 2011), 890.

35 Ahkamul Fuqaha, Solusi Problematika Aktual Hukum Islam Keutusan Muktamar, Munas, Konbes Nahdlatu Ulama 1926-2010 M (Surabaya: Lajnah

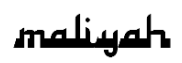


Berdasarkan hal tersebut, diketahui bahwa hukum jual beli online (as-salam) sah didasarkan pada al-Qur'an dan hadis. Dasar hukum yang terdapat dalam al-Qur'an diantaranya adalah QS. an-Nisa': 29:

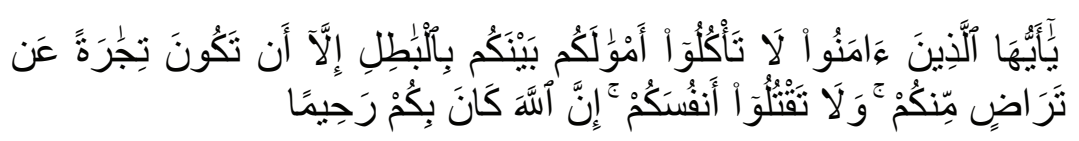

Hai orang-orang yang beriman, janganlah kamu saling memakan harta sesamamu dengan jalan yang batil, kecuali dengan jalan perniagaan yang berlaku dengan suka sama-suka di antara kamu. Dan janganlah kamu membunuh dirimu; sesungguhnya Allah adalah Maha Penyayang kepadamu. ${ }^{36}$

Sedangkan dalam hadis berdasarkan riwayat dari Abu Said al-Khudri bahwa Rasulullah SAW bersabda: "Sesungguhnya jual beli itu harus dilakukan suka sama suka." (HR. AlBaihaqi dan Ibnu Majah, dan dinilai shahih oleh Ibnu Hibban).

Dan juga dalam hadits riwayat Bukhari dari Ibn Abbas, Nabi bersabda: "Barang siapa melakukan salaf (salam), hendaknya ia melakukan dengan takaran yang jelas dan timbangan yang jelas untuk jangka waktu yang diketahui" (HR. Bukhari, Shahih al-Bukhari (Beirut: Dar al-Fikr, 1955) jilid 2, h. 36).

\section{Penutup}

Berdasarkan penjelasan tentang hukum jual beli secara online adalah boleh sebagaimana pendapat para ulama, yang didasarkan pada al-Qur'an dan hadis.

Akad jual beli secara online adalah sah jika telah memenuhi rukun dan syarat jual beli diantaranya dengan ketentuan barang yang dibeli halal dan jelas spesifikasinya, barang yang akan dibeli adalah barang yang memang

Ta'lif Wan Nasyr (LTN) Pengurus Besar Nahdlatul Ulama dan Khalista, 2011), 890.

36 Departemen Agama RI, Al-Qur'an Dan Terjemahnya (Jakarta: Departemen Agama RI, n.d.), 107.

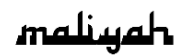


dibutuhkan sehingga tidak menyebabkan tabzir, pembeli memiliki hak untuk mengembalikan atau membatalkan jual beli jika barang yang dibeli tidak sesuai pesanan, dan jual beli online harus dilakukan sesuai dengan skema jual beli.

Jual beli tersebut dianggap fi hukm ittihad al-majlis (dalam posisi satu majelis). Ittihad al-majlis bisa diartikan dengan tiga hal yaitu ittihad al-makan (satu tempat) dan ittihad al-zaman (waktu waktu), dan ittihad al-haiah (satu posisi). Dengan adanya media komunikasi modern, bisa menyatukan dua tempat yang berjauhan, sehingga kedua tempat tersebut dianggap menjadi satu (taaddud al-makan fi manzilah ittihad al-makan). Transaksi jual beli online yang dilakukan di dua tempat yang berjauhan termasuk dalam ittihad al-majlis dalam kategori ittihad al-zaman (satu waktu).

\section{Daftar Pustaka}

Al-Faifi, Sulaiman. Ringkasan Fiqih Sunnah Sayyid Sabiq. Depok: Senja Media Utama, 2017.

Al-Fauzan, Saleh. Fiqih Praktis Sehari-Hari. Jakarta: Gema Insani, 2005.

Al-jaziri, Abdulrahman. Fiqih Empat Madzhab. Semarang: CV Asy-Syifa, 1994.

Bahreysi, Budi. "Perlindungan Hukum Bagi Konsumen Dalam Jual Beli Secara Online." De Lega Lata: Jurnal Ilmu Hukum 3, no. 2 (2018). http://journal.umsu.ac.id/index.php/delegalata/article/vi ew/3157/2873.

Departemen Agama RI. Al-Qur'an Dan Terjemahnya. Jakarta: Departemen Agama RI, n.d.

Dewan Syariah Nasional MUI. "Fatwa DSN MUI No. 04/DSNMUI/IV/2000 Tentang Murabahah." Jakarta, 2000.

Endriani, Santi. "Konsep Uang: Ekonomi Islam vs Ekonomi Konvensional." Anterior 15, no. 1 (2015).

Fuqaha, Ahkamul. Solusi Problematika Aktual Hukum Islam Keutusan Muktamar, Munas, Konbes Nahdlatu Ulama 19262010 M. Surabaya: Lajnah Ta'lif Wan Nasyr (LTN) Pengurus Besar Nahdlatul Ulama dan Khalista, 2011. 
Ghazali, Abdul Rahman. Fiqih Muamalat. Jakarta: Fajar Interpratama Offset, 2010.

Harun, Nasrun. Fiqih Muamalah. Jakarta: Gaya Media Pratama, 2007.

Khosyi'ah, Siah. Fiqih Muamalah Perbandingan. Bandung: CV Pustaka Setia, 2014.

"Konsultasi Syariah Fikih Belanja Online." Republika.Co.Id, October 18 , 2008. http://m.republika.co.id/berita/ekonomi/syariahekonomi/18/10/08/pg8ieo370-konsultasi-syariah-fikihbelanja-online.

Majelis Ulama Indonesia. "Fatwa Majelis Ulama Indonesia Nomor 24 Tahun 2017 Tentang Hukum Dan Pedoman Bermuamalah Melalui Media Sosial." Jakarta, 2017.

MUI, Dewan Syari'ah Nasional. "Fatwa Dewan Syari'ah Nasional No: 05/DSN-MUI/IV/2000 Tentang Jual Beli Salam." Jakarta, 2000.

Napitupulu, Rodame Monitorir. "Pandangan Islam Terhadap Jual Beli Online." At-Tijaroh 1, no. 2 (2015). http://repo.iain-padangsidimpuan.ac.id/293/1/Rodame Monitorir Napitupulu.pdf.

Nisrina, Disa Nusia. "Tinjauan Hukum Islam Terhadap Jual Beli Online Dan Relevansinya Terhadap Undang-Undang Perlindungan Konsumen." UIN Alauddin Makassar, 2015.

Pekerti, Retno Dyah, and Eliada Herwiyanti. "Transaksi Jual Beli Online Dalam Perspektif Syariah Madzhab Asy-Syafi'i." Jurnal Ekonomi, Bisnis, Dan Akuntansi 20, no. 2 (2018). http://jp.feb.unsoed.ac.id/index.php/jeba/article/view/1 108.

Rival, Veithzal, and Andi Buchari. Islamic Economics : Ekonomi Syariah Bukan OPSI, Tapi Solusi! Jakarta: Bumi Aksara, 2009.

Riyanti, Umi. "Jual Beli Barter Dalam Perspektif Ekonomi Syariah." IAIN Palangkaraya, 2016.

Salim, Munir. "Jual Beli Secara Online Menurut Pandangan Hukum Islam." Ad-Daulah 6, no. 2 (2017).

Suhendi, Hendi. Fiqh Muamalah. Jakarta: PT Raja Grafindo

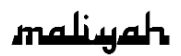


Hukum Jual Beli melalui Media Sosial ...

Persada, 2013.

Susiawati, Wati. "Jual Beli Dalam Konteks Kekinian." Jurnal Ekonomi Islam 8, no. 2 (2017). https://journal.uhamka.ac.id/index.php/jei/article/view/ 836. 